Acta Universitatis Nicolai Copernici • Pedagogika XXIX/2013

Nauki Humanistyczno-Społeczne • Zeszyt 421

http://dx.doi.org/10.12775/AUNC_PED.2013.002

\title{
Daria Hejwosz-Gromkowska
}

Wydział Studiów Edukacyjnych

Uniwersytet im. Adama Mickiewicza w Poznaniu

\section{IDEA GLOBALNEGO OBYWATELSTWA}

\section{A PROBLEM NAUCZANIA HISTORII \\ - ZALOŻENIA A RZECZYWISTOŚć}

TMostatnich latach pojawiła się „moda” na dyskusje dotyczące celów nauczania historii na poziomie szkolnictwa obowiązkowego w państwach zachodnich. Dyskusje te stanowią odpowiedź na tzw. kryzys wiedzy historycznej. Zainteresowanie tym problemem widać szczególnie w Wielkiej Brytanii ${ }^{1}$. Wydaje się bowiem, że w społeczeństwach zachodnich rozprzestrzenił się „wirus amnezji historycznej”. Badania pokazują, że młodzi Amerykanie, Brytyjczycy czy Niemcy nie znają historii narodowej². Niewątpliwie młodym ludziom na całym

\footnotetext{
1 Zob. Debates in teaching history, red. I. Davies, Routledge, Oxon-New York 2011.

${ }^{2}$ P. Gounari, Unlearning the official history: agency and pedagogies of possibility, [w:] Ideologies in education. Unmasking the trap of teaching neutrality, red. L. I. Bartolome, Peter Lang, New York 2008, s. 98; Adres internetowy: http://wiadomosci.onet. $\mathrm{pl}$ /regionalne/wielka-brytania-i-Irlandia/brytyjczycy-nie-znaja-historii,1,5189275,wiadomosc.html; http://www.guardian.co.uk/commentisfree/2012/jul/01/barbara-ellen -german-kids-nazism; http://www.dailymail.co.uk/news/article-2046371/Teenage -pupils-believe-Winston-Churchill-TV-advert-dog.html http://www.welt.de/regionales/duesseldorf/article108390398/Schueler-halten-Nazi-Deutschland-fuer-Demo kratie.html, dostęp 2.08.2012.
} 
świecie łatwiej przychodzi rozpoznanie postaci związanych z kulturą popularną niż wymienienie najważniejszych dat w historii swojego narodu ${ }^{3}$. W tym kontekście należy bowiem zwrócić uwagę, że tożsamość współczesnych globalnych nastolatków w większym stopniu kształtowana jest przez kulturę popularną niż narodową ${ }^{4}$. W świecie globalnym dominuje kultura kosmopolityczna, zatem różnice kulturowe, które niegdyś dzieliły naszych przodków, współcześnie zanikają. W tej globalnej rzeczywistości promuje się odejście od modernistycznej koncepcji obywatelstwa, rozumianej jedynie jako zbiór praw i obowiązków wobec konkretnego państwa narodowego, na rzecz globalnego obywatelstwa. W sferze praktyki pedagogicznej problemy i konteksty globalne włączane są do szkolnych programów nauczania ${ }^{5}$.

Lekcje historii oraz geografii są głównymi przedmiotami szkolnymi, w ramach których można uczyć o problemach globalnych. Implikuje to nowe wyzwania nie tylko dla nauczycieli tych przedmiotów, ale również dla tych, którzy tworzą programy kształcenia, zarówno w zakresie doboru tematyki zajęć, jak i w sferze metodyki nauczania. Historia narodowa, szczególnie w podejściu konserwatywnym, postrzegana jest jako jeden $\mathrm{z}$ elementów $\mathrm{w}$ procesie narodowotwórczym ${ }^{6}$. Istnieje przekonanie, że lekcje historii rozwijają poczucie lojalności oraz tożsamości narodowej, a także przyczyniają się do wykształcenia postaw obywatelskich7 ${ }^{7}$ Warto jednak zadać pytania dotyczące celów nauczania historii w kontekście wyzwań, jakie stawia globalizacja. W jaki sposób nauczać historii, aby kształtować poczucie tożsamości narodo-

3 Por. P. Gounari, Unlearning the official history, dz.cyt., s. 102.

4 Zob. Prace Zbyszko Melosika poświęcone kategorii globalnego nastolatka, m.in. Z. Melosik, Teoria i praktyka edukacji wielokulturowej, Impuls, Kraków 2007.

5 Zob. Adres internetowy: http://www.ceo.org.pl/pl/globalna, dostęp 12.06. 2012.

6 W. Kymlicka, Contemporary political philosophy. An Introduction, Oxford University Press, Oxford 2002, s. 263.

7 Zob. K. C. Barton, L. S. Levstik, History, w: Education for citizenship and democracy, red. J. Arthur, I. Davies, C. Hahn, Sage, London 2008; E. Callan, Democratic patriotism and multicultural education, [w:] Education, democracy, and the moral life, red. M. S. Katz, S. Verducci, G. Biesta, Springer 2008. 
wej z jednej strony, a z drugiej wrażliwość na problemy globalne? Czy możliwe jest znalezienie równowagi między orientacją na państwo narodowe a orientacją globalną w procesie nauczania historii, i czy jest to konieczne? W niniejszym artykule podejmę próbę rekonstrukcji zachodniej debaty dotyczącej nauczania historii i wychowywania globalnych obywateli. Wydaje się, że przywołanie stanowisk zachodnich badaczy ma znaczenie w kontekście toczącej się ostatnio w Polsce dyskusji na temat zmiany podstawy programowej, w której edukacja historyczna ma być powiązana z edukacją obywatelską ${ }^{8}$. W celu uzyskania szerszej perspektywy odwołam się również do współczesnej krytyki nauczania historii, jak również do krytyki globalnego obywatelstwa.

\section{Procesy globalizacyjne}

\section{ICH SPOŁECZNO-EDUKACYJNE KONSEKWENCJE}

Myliłby się ten, kto uważa, że procesy globalizacyjne dzieją się „gdzieś tam" i nie mają wpływu na codzienne życie ludzi. Jak zauważa Anthony Giddens: „globalizacja to zjawisko rozgrywające się «tutaj», które wpływa na najbardziej intymne aspekty naszego życia (czy raczej jest z nimi w dialektyczny sposób powiązane)"9. Za badaczami przedmiotu można wyróżnić kilka aspektów globalizacji, którymi są mobilność, eksterytorialność, osłabienie roli państwa narodowego, tworzenie społeczeństw wielokulturowych, kosmopolityczna kultura, nierówności społeczne i ekonomiczne.

W mobilnym świecie zanika poczucie przynależności do miejsca, a terytorium odgrywa coraz mniejszą rolę $\mathrm{w}$ procesie kształtowania tożsamości. Odległości, które dawniej stanowiły barierę w przemieszczaniu się ludzi, dziś wyraźnie się skurczyły. Przestrzeń między jednym a drugim punktem można zmierzyć za pomocą szybkości jej

8 Adres internetowy: http://www.men.gov.pl, dostęp 20.08.2012.

9 A. Giddens, Życie $w$ społeczeństwie posttradycyjnym, w: Modernizacja refleksyjna, U. Beck, A. Giddens, S. Lash, Wydawnictwo Naukowe PWN, Warszawa 2009, s. 129. 
pokonania ${ }^{10}$. Jednym ze skutków zwiększonej mobilności ludzi jest tworzenie się wielokulturowych społeczeństw, a także kształtowanie się jednej, ponadnarodowej, kosmopolitycznej kultury ${ }^{11}$. Jak słusznie zauważa Anthony Giddens, współcześnie jesteśmy świadkami „kosmopolitycznej rozmowy ludzkości"12, z kolej Barry Smart twierdzi, że nasza kultura przekształca się w globalny monolit ${ }^{13}$. A zatem można by rzec, że to, co dawniej było postrzegane w kategoriach kultury narodowej, wyparte zostaje przez eklektyczną, hybrydyczną, sfragmentaryzowaną globalną kulturę ${ }^{14}$. Globalizacja w tym przypadku przyczynia się do unifikacji i standaryzacji kulturowej, aczkolwiek należy zauważyć, że również obserwujemy zjawiska glokalizacji i kreolizacji ${ }^{15}$.

Siły globalne oddziałują na kondycję państwa narodowego, a także na jego wewnętrzną politykę. Niektórzy badacze przedmiotu zauważają, że globalizacja przyczyniła się do osłabienia jego roli, inni z kolei stoją na stanowisku, iż nadal pozostaje on głównym rozgrywającym na politycznej arenie. Anthony D. Smith dostrzega, że państwo narodowe utraciło wiele ze swych wcześniejszych funkcji, ale jego jedność polityczna nie została zachwiana ${ }^{16}$. Podobne stanowisko zajmuje Ulrich Beck, który zauważa, że z jednej strony mamy do czynienia z osłabieniem państwa w społeczeństwie ryzyka, z drugiej zaś, jest ono obecnie potrzebne bardziej niż kiedykolwiek wcześniej ${ }^{17}$. Z kolei Manuel

10 Z. Bauman, Globalizacja. I co z tego dla ludzi wynika, Państwowy Instytut Wydawniczy, Warszawa, 1999, s. 17-23; por. Rekonstrukcje tożsamości w kulturze natychmiastowości, red. D. Hejwosz-Gromkowska, Wydawnictwo Naukowe UAM, Poznań 2014.

11 Zob. Z. Melosik, Teoria i praktyka, dz.cyt.; J. E. Lane, Globalization and politics. Promises and dangers, Ashgate, Hampshire 2006; A. Giddens, Życie w społeczeństwie posttradycyjnym, dz.cyt.

12 A. Giddens, Życie w społeczeństwie posttradycyjnym, dz.cyt., s. 135.

13 B. Smart, Postmodernizm, Zysk i Ska, Poznań 1998, s. 183.

14 A. D. Smith, Nacjonalizm, Wydawnictwo Sic!, Warszawa 2007, s. 175.

15 Zob. Z. Melosik, Teoria i praktyka, dz.cyt., s. 13-23.

16 A. D. Smith, Nacjonalizm, dz.cyt., s. 163.

17 U. Beck, Ponowne odkrycie polityki: przyczynek do teorii modernizacji refleksywnej, w: Modernizacja refleksyjna. Polityka, tradycja i estetyka w porządku społecznym nowoczesności, U. Beck, A. Giddens, S. Lash, Wydawnictwo Naukowe PWN, Warszawa 2009, s. 60. 
Castells dostrzega wyraźne osłabienie państwa narodowego na skutek procesów globalizacji ${ }^{18}$. Natomiast według Zbyszko Melosika, zwolennicy kryzysu państwa narodowego utrzymują, że władza „opuszcza centrum i przemieszcza się «w górę» (poziom ponadnarodowy), «na boki» (poziom międzynarodowy), «W dół» (poziom lokalny)"19.

$\mathrm{Z}$ perspektywy interesującego nas problemu nauczania historii w kontekście wychowywania globalnych obywateli warto również wspomnieć, za badaczami przedmiotu, że wraz z osłabieniem roli państwa narodowego, zmniejsza się także poczucie przynależności do narodu. Podążając za rozważaniami Baumana, można stwierdzić, że współcześnie jednostki są mniej skłonne do poświęceń wobec państwa i narodu ${ }^{20}$. Wielkie metanarracje, które mówiły o poświęceniu dobra osobistego, czy nawet życia, w imię ojczyzny, narodu, państwa, stają się dziś mało wiarygodne. Jednostki, które tworzyły wspólnotę w dobie nowoczesności i dla których była ona swoistym azymutem, dziś dryfują samodzielnie. Dodatkowo poczucie miejsca i przestrzeni, które określało przynależność historyczną i geograficzną, także traci na znaczeniu („koniec historii”; „koniec geografii”).

W tym kontekście warto zauważyć, że naród przestaje być jedynym, czy też głównym punktem odniesienia dla kształtowania tożsamości. Współcześnie badacze przedmiotu dostrzegają jej procesualny charakter (Z. Bauman, A. Jawłowska) ${ }^{21}$, przypisuje się jej fragmentaryczność oraz hybrydyczność (Z. Bauman, M. Castells, L. Grossberg, Z. Melosik) ${ }^{22}$. Tożsamość współczesnych jednostek staje się zatem kru-

18 M. Castells, Siła tożsamości, Wydawnictwo Naukowe PWN, Warszawa 2009, s. 278.

19 Z. Melosik, Teoria i praktyka, dz.cyt., s. 14.

20 Zob. Z. Bauman, Tożsamość - jak była, jest i po co?, w: Wokół problemów tożsamości, red. A. Jawłowska, Wydawnictwo LTW, Warszawa 2001.

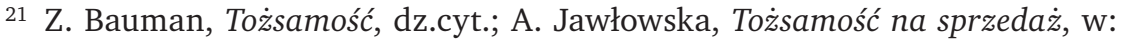
Wokót problemów tożsamości, red. A. Jawłowska, Wydawnictwo LTW, Warszawa 2001.

22 Z. Bauman, Tożsamość, dz.cyt.; Z. Bauman, Tożsamość ze sklepu, tożsamość ze spiżarni, w: Kultura popularna $i$ (re) konstrukcje tożsamości, red. A. Gromkowska-Melosik, Poznań-Leszno 2007; L. Grossberg, Tożsamość i studia kulturowe: tendencje rozwojowe i alternatywy, [w:] Kultura popularna i (re) konstrukcje tożsamości, dz.cyt.; Z. Melosik, Wychowanie obywatelskie: nowoczesność, pono- 
cha, niespójna, fragmentaryczna, podlega ona ciągłemu (re)konstruowaniu.

Nie ulega zatem wątpliwości, że w zglobalizowanym, ponowoczesnym świecie, w którym następuje kryzys państwa narodowego i osłabienie więzi wspólnotowych, pojawia się również kryzys tożsamości narodowej. Warto zauważyć, że w ujęciu interakcjonistycznym to, kim jesteśmy, jest określane przez relacje między naszą wspólnotą wyobrażoną ${ }^{23}$ a „innymi” ${ }^{24}$. W tym podejściu ważna dla kształtowania tożsamości jest relacja „my-oni”, w zglobalizowanym świecie ta dystynkcja staje się problematyczna ${ }^{25}$. Wydaje się, że kultura kosmopolityczna zrywa z tym podziałem. Coraz trudniej jest rozróżnić to co „nasze, narodowe”, od tego co „obce”. Aldona Jawłowska twierdzi, że tożsamość narodowa pojawia się najczęściej w sytuacji zagrożenia, wówczas, gdy trzeba jej bronić. Zauważa przy tym, że „trudno dziś mówić o poczuciu tożsamości, która buduje się na podstawie wspólnych wartości kultury narodowej, gdyż kanon tej kultury się rozpada"26. Następuje również zmierzch bohaterów narodowych ${ }^{27}$ i, jak zauważa Anthony Smith: „«heroiczna» wizja tożsamości narodowej, oparta na motywach walki, wyzwolenia i poświęcenia, typowa dla od niedawna niezależnych narodów czy «państw narodowych», może w następnym pokoleniu ustąpić miejsca bardziej otwartym, pragmatycznym i funkcjonalnym typom tożsamości narodu, akcentującym takie wartości, jak: przedsiębiorczość, zdolności organizacyjne i tolerancja dla różnorodności - wartości wywodzących się z odmiennych tradycji etnicznych

woczesność. (Próba konfrontacji), w: Wychowanie obywatelskie. Studium teoretyczne, porównawcze i empiryczne, red. Z. Melosik, K. Przyszczypkowski, Poznań-Toruń 1998.

${ }^{23}$ Koncepcja wspólnoty wyobrażonej została zaproponowana przez Benedicta Andersona, który popierał wersję umiarkowanej teorii antynacjonalistycznej.

${ }^{24}$ M. Budyta-Budzyńska, Socjologia narodu i konfliktów etnicznych, Wydawnictwo Naukowe PWN, Warszawa 2010, s. 96.

${ }^{25}$ Można przyjąć, że kategoria „oni” będzie przypisywana tym jednostkom, które z jakiś przyczyn (społecznych, ekonomicznych, politycznych) nie są uczestnikami pierwszego, zglobalizowanego świata.

${ }^{26}$ A. Jawłowska, Tożsamość na sprzedaż, dz.cyt., s. 60.

27 Tamże. 
występujących w historii narodu"28. Wydaje się, że stanowisko Smitha jest coraz bardziej bliskie prawdy, jako że promowana koncepcja „obywatela świata", zaznacza swoją obecność w społecznym dyskursie.

\section{IDEA GLOBALNEGO OBYWATELSTWA I JEJ KRYTYKA}

W świetle powyższych rozważań odnoszących się do procesów globalizacyjnych i problemów z tożsamością warto przybliżyć ideę globalnego obywatelstwa. Współczesna koncepcja obywatelstwa - eksponująca zwłaszcza jego kosmopolityczny wymiar - zasadniczo różni się od tych, które powstawały tuż po zakończeniu II wojny światowej. Od tamtego czasu, jak podaje Will Kymlicka, do koncepcji obywatelstwa zaczęto włączać kategorię tożsamości, skupiając się także na jego indywidualnym wymiarze, który oznacza odpowiedzialność i lojalność jednostki, a także powiązane jest z pełnieniem roli społecznej ${ }^{29}$. Wydaje się jednak, że współcześni teoretycy mają trudności ze zdefiniowaniem, czym jest obywatelstwo. Problemy te mogą wynikać z faktu, że ramy, w których tworzona była jego klasyczna koncepcja, legły w gruzach wraz z nastaniem epoki ponowoczesności. Widać zatem, że koncepcja obywatelstwa stanowi zmienną konstrukcję społeczną ${ }^{30}$.

Hugh Starkey zauważa, że pojęcie obywatelstwa może być rozumiane jako status, uczucie oraz praktyka. Status powiązany jest z prawnym wymiarem obywatelstwa, przypisuje mu się często charakter narodowy (np. obywatel Polski), który w społeczeństwach wielokulturowych postrzegany jest jako źródło nierówności społecznych $^{31}$. Uczuciowy aspekt obywatelstwa odnosi się do poczucia przynależności do konkretnej wspólnoty ${ }^{32}$. Z kolei praktyczny wymiar

28 A. D. Smith, Nacjonalizm, dz.cyt., s. 34.

29 W. Kymlicka, Contemporary political, dz.cyt., s. 286.

30 Por. Z. Melosik, Obywatelstwo, czas (historia) i przestrzeń (geografia), w: Wychowanie obywatelskie. Studium teoretyczne, porównawcze i empiryczne, dz.cyt.; Z. Melosik, Wychowanie obywatelskie, dz.cyt.

31 H. Starkey, Antiracism, w: Education for citizenship and democracy, red. J. Arthur, I. Davies, C. Hahn, Sage, London 2008, s. 331.

32 Tamże. 
obywatelstwa dotyczy uczestnictwa w demokratycznym społeczeństwie oraz przestrzegania praw człowieka ${ }^{33}$. Z tej perspektywy wydaje się, że koncepcja globalnego obywatelstwa nie zawiera w sobie tych trzech wymiarów. Nie istnieje bowiem instytucja, która na mocy prawa może nadać status obywatela świata. Termin „obywatel świata”, w tej pespektywie jest semantycznie niespójny. Koncepcja obywatelstwa określa relację między jednostką a państwem, a nie istnieje państwo-świat, dlatego nie można mówić o koncepcji obywatela świata $^{34}$. Trudno również mówić o możliwości generowania uczuć takich, jak odpowiedzialność, lojalność, przywiązanie wobec całego globu³5. Z tej perspektywy państwo narodowe ciągle jawi się jako punkt wyjścia dla budowania tożsamości obywatelskiej czy narodowej. Wydaje się, że jedynie sfera praktyczna odnajduje do pewnego stopnia zastosowanie w przypadku obywatelstwa globalnego. Aczkolwiek trudno jest podjąć działania na rzecz jakiejś sprawy, jeśli nie pojawia się zaangażowanie emocjonalne ${ }^{36}$.

Przyjmuje się jednak, że wychowanie globalnych obywateli ma na celu kształtowanie w młodych ludziach gotowości do podejmowania odpowiedzialnych działań w wymiarze ochrony środowiska, likwidacji nierówności społecznych, utrzymywania pokoju oraz różnorodności kulturowej na całym świecie ${ }^{37}$. Graham Pike zwraca uwagę, że koncepcja globalnego obywatelstwa ma swe źródła zarówno w wychowaniu obywatelskim, jak i w edukacji globalnej, toteż wartości takie, jak: demokracja, prawa człowieka, pokój stanowią rdzeń dla omawianej idei ${ }^{38}$. Z ekonomicznego punktu widzenia globalny obywatel „pracuje efektywnie gdziekolwiek się znajdzie na świecie, a globalny

33 Tamże, s. 332.

34 D. Heater, A history of education for citizenship, Routledge Falmer, London-New York 2004, s. 195.

35 Zob. tamże.

36 A. Osler, Patriotism, multiculturalism and belonging: political discourse and the teaching of history, "Educational Review", t. 61, nr 1, luty 2009, s. 97.

37 Zob. N. Noddings, Educating citizens for global awareness, Teachers College Press, New York 2005.

38 G. Pike, Global education, w: Education for citizenship and democracy, red. J. Arthur, I. Davies, C. Hahn, Sage, London 2008, s. 474. 
styl życia wzmacnia istnienie globalnego obywatelstwa"39. Jednak globalne obywatelstwo ma nie tylko wymiar ekonomiczny, chociaż wydaje się, że ten aspekt stanowi główną oś, wokół której buduje się tę kategorię. Dla Peggy McIntosh globalne obywatelstwo to stan „serca i umysłu" ${ }^{40}$, a zatem to zbiór pewnych uniwersalnych wartości ${ }^{41}$, które wpisane są w Powszechną Deklarację Praw Człowieka. Badacze przedmiotu (Noddings, Pike, Banks) nawołują zatem, aby w sferze praktyki pedagogicznej uczniowie nabywali wiedzę i umiejętności, które ukształtują z nich aktywnych obywateli w globalnej społeczności ${ }^{42}$.

Idea globalnego obywatelstwa, mimo że tak aktywnie promowana, wydaje się kolejną ideologią nawiązującą do lewicowych tradycji. Ugrupowania prawicowe widzą $\mathrm{w}$ tym podejściu niebezpieczeństwo rozpadu państwa narodowego, gdyż w procesie wychowania obywatelskiego uczniom nie zaszczepia się lojalności wobec narodu i państwa. Jednocześnie podejście kosmopolityczne zrywa z tradycyjnym podejściem zorientowanym na państwo narodowe. Warren A. Nord zauważa, że osoby związane z prawym skrzydłem sceny politycznej obawiają się zjawiska fragmentaryzacji kulturowej oraz moralnego relatywizmu. Natomiast lewica obawia się tradycjonalizmu i opresji wobec grup mniejszościowych ${ }^{43}$.

W przypadku omawianej koncepcji punktem wyjścia przestaje być państwo narodowe, mamy jedynie do czynienia z punktem dojścia do koncepcji globalnego obywatelstwa. Wychowanie obywatelskie, za-

39 N. Noddings, Educating citizens, dz.cyt., s. 3.

40 P. McIntosh, Gender perspective on education for global citizenship, w: Educating citizens for global awareness, red. N. Noddings, Teachers College Press, New York 2005, s. 23.

41 Zob. A. Osler, Human Rights Education: The Foundation of education for democratic citizenship in our global age, w: Education for citizenship and democracy, red. J. Arthur, I. Davies, C. Hahn, Sage, London 2008, s. 457.

42 J. A. Banks, Diversity and citizenship education in global times, w: Education for citizenship and democracy, red. J. Arthur, I. Davies, C. Hahn, Sage, London 2008, s. 61; M. M. Merryfield, L. Duty, Globalization, w: Education for citizenship and democracy, red. J. Arthur, I. Davies, C. Hahn, SAGE, 2008, s. 88.

43 W. A. Nord, Disagreement, moral education, common ground, w: Making good citizens. Education and civil society, red. D. Ravitch, J. P. Viteritti, Yale University Press, New Haven \& London 2001, s. 142. 
uważa Heater, stanowi wychowanie dla państwa, natomiast wychowanie obywateli świata staje się problematyczne także z punktu praktyki pedagogicznej. Oto bowiem nauczyciele musieliby nauczać o całym świecie, co w opinii przywołanego badacza, wydaje się niemożliwe. Utrzymuje on, że koncepcja „wychowania obywateli świata” stanowi jedynie echo w sferze pedagogicznej, ujawniając się w akademickiej debacie dotyczącej uprawomocnienia tej koncepcji ${ }^{44}$. Wydaje się, że w poszukiwaniu możliwych strategii wychowania obywatelskiego, model globalnego/światowego obywatela stanowi bardziej konstrukcję teoretyczną niż pragmatyczną. D. Heater zauważa, że o ile w literaturze przedmiotu przypisuje się duże znaczenie temu wymiarowi obywatelstwa, o tyle istnieje niewiele wypracowanych metod w zakresie

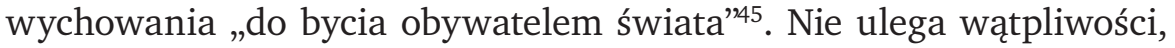
że z globalnym/światowym obywatelstwem łączy się tolerancja i respektowanie praw grup kulturowych oraz wzajemne współistnienie, które niweluje napięcia społeczne. Jednakże na tym etapie tworzenia się tej koncepcji, nie jest do końca jasne, jaka wiedza (czyja wiedza) powinna być przekazywana. Jeśli bowiem celem wychowania globalnych/światowych obywateli miałoby być zastąpienie narodowej historii historią światową, wiedza ta musiałaby być wyselekcjonowana oraz powierzchowna ${ }^{46}$. Z tej perspektywy pojawia się ponownie pytanie o to, kto i w jaki sposób powinien dokonywać tej selekcji? Czyja wiedza i czyja prawda powinna być uznana?

\section{NAUCZANie histori W PERSPEKTYWIE GLOBALNEJ - PRÓbA KONFRONTACJI PODEJŚć}

Nie ulega wątpliwości, że procesy globalizacyjne oddziałują również na systemy oświatowe na całym świecie. W wyniku procesów (za) pożyczania rozwiązań w sferze edukacji, a także ich implementacji, szkolnictwo na całym świecie staje się coraz bardziej ujednolicone. Nie

\footnotetext{
44 D. Heater, A history of education for citizenship, dz.cyt., s. 226.

45 Tamże, s. 232.

46 Tamże.
} 
oznacza to jednak, że szkoły na całym świecie będą takie same, musimy bowiem pamiętać o procesach glokalizacji, jednak w sferze edukacji dąży się szczególnie do uniformizacji i standaryzacji programów kształcenia ${ }^{47}$. Kolejną konsekwencją globalizacji edukacji jest wprowadzanie do programów szkolnych edukacji globalnej, której celem jest wychowywanie globalnych obywateli. Badacze i praktycy edukacji globalnej uważają, że wiedza oraz umiejętności z tego zakresu nie powinny być przekazywane $\mathrm{w}$ ramach odrębnego przedmiotu, lecz należy wprowadzać je do istniejących, takich jak historia, geografia, wiedza o społeczeństwie, jak również do przedmiotów ścisłych. Promuje się zatem podejście holistyczne i interdyscyplinarne, a także niweluje się potencjalne „przeładowanie” i tak obciążonego programu kształcenia ${ }^{48}$.

W związku z procesami globalizacyjnymi badacze przedmiotu na podstawie analizy programów kształcenia zauważają, że mają one ciągle charakter etnocentryczny i nacjonalistyczny. O ile system szkolnictwa był obiektem krytyki wielu badaczy i teoretyków przedmiotu, reprezentujących głównie nurt pedagogiki krytycznej (Illich, Freire, Giroux, Szkudlarek, Śliwerski, etc.), o tyle w kontekście procesów globalizacyjnych dochodzi dodatkowy argument odnośnie do niedostosowywania się systemu do gwałtownie zmieniającego się otoczenia. Przykładowo Rita Süssmuth zauważa, że większość systemów edukacyjnych na całym świecie nie jest przygotowana, aby sprostać wyzwaniom globalizacji i konsekwencjom imigracji ${ }^{49}$. Marcelo M. Suarez-Orozco i Carolyn Sattin wysuwają podobne wnioski, twierdząc, że dzieci imigrantów w społeczeństwach wielokulturowych już na początku skazane są na marginalizację ${ }^{50}$. Zwraca się przy tym uwagę

47 J. Spring, Globalization of education. An introduction, Routledge, New York London 2009, s. 2.

48 Zob. S. J. Thornton, Incorporating internationalism into social studies curriculum, w: Educating citizens for global awareness, red. N. Noddings, Teachers College Press, New York 2005.

49 R. Süssmuth, On the need for teaching intercultural skills, w: Learning in the global era. International perspectives on globalization and education, red. M. M. Suarez-Orozco, University of California Press, Ross Institute, Berkeley, Los Angeles-London 2007, s. 197.

50 Tamże, s. 3. 
na brak łączności między rzeczywistością, w której żyją młodzi ludzie (globalna, kosmopolityczną, konsumpcyjną, wielokulturową), a rzeczywistością szkolną (zakonserwowaną, lokalną, etnocentryczną, nacjonalistyczną).

W kontekście wychowania globalnych obywateli, a także rozwoju wielokulturowych społeczeństw, współczesne podejście do nauczania historii jest krytykowane. W literaturze przedmiotu można odnaleźć trzy główne obszary krytyki, które postaram się pokrótce zrekonstruować ${ }^{51}$.

Po pierwsze, zakłada się brak związku między nauczaniem historii a teraźniejszościa. W konsekwencji młodzi ludzie nie są zainteresowani uczeniem się historii, nie odnajdują bowiem relacji między wydarzeniami historycznymi a ich życiem. Panayota Gounari zauważa, że wirus amnezji historycznej dotknął niemalże wszystkie zachodnie społeczeństwa ${ }^{52}$. Być może rację miał Francis Fukuyama, który zapowiedział „koniec historii”, jak również Alvin Toffler, który wskazywał, że żyjemy w „szoku przyszłości”. Należy zwrócić uwagę, że tożsamości współczesnych ludzi mają charakter hybrydyczny, z kolei tożsamość młodych ludzi bardziej konstruowana jest na podstawie tego, co globalne, a nie narodowe ${ }^{53}$. Współcześnie, jak wskazują Keith Barton i Linda S. Levstik, nie ma zgody, odnośnie do tego, czy istnieje relacja między nauczaniem historii a kształtowaniem się postaw obywatelskich ${ }^{54}$.

Nel Noddings pokazuje, że młodzi ludzie są bardziej zainteresowani kwestiami, które mają związek z ich własnym życiem, takimi jak: znaczenie patriotyzmu, rozumienie propagandy, psychologii wojny i w jaki sposób niszczy ona morale. Jeśli te elementy zostaną włą-

51 Więcej na ten temat, zob. D. Hejwosz-Gromkowska, Citizenship education and history. Setting the scene, w: Historia ludzi. Historia dla ludzi. Krytyczny wymiar edukacji historycznej, red. I. Chmura-Rutkowska, E. Głowacka-Sobiech, I. Skórzyńska, Kraków 2013; D. Hejwosz-Gromkowska, Wychowanie obywatelskie a problem nauczania historii rekonstrukcja zachodniej debaty, „Kultura-Społeczeństwo-Edukacja", nr 1 (3)/2013.

52 P. Gounari, Unlearning the official history, dz.cyt., s. 99.

53 Tamże, s. 102.

54 K. C. Barton, L. S. Levstik, History, dz.cyt., s. 356. 
czone przy omawianiu konkretnego wydarzenia historycznego, np. II wojny światowej, wojny na Bałkanach, wówczas, w opinii Noddings, stają się one bardziej realistyczne dla nich i wpływają na ich rozwój jako globalnych obywateli ${ }^{55}$. Z kolei Marcelo M. Suarez-Orozco i Carolyn Sattin idą o krok dalej, twierdząc, że system szkolny nie zmienia się tak gwałtownie, jak jego zewnętrzne otoczenie, a treści przekazywane uczniom nie są dostosowane do ich zainteresowań, dlatego szkoła jawi się uczniom jako nudne miejsce ${ }^{56}$. W tym kontekście zarówno Gounari, jak i Levstik oraz Barton pokazują, że ważnym wyzwaniem dla nauczania historii jest umiejętność powiązania wydarzeń historycznych z teraźniejszością, ale również z przyszłością, tak aby tworzyły one triadę przeszłość - teraźniejszość - przyszłość 57 .

Po drugie, przyjmuje się, że współczesne, modernistyczne „podejście do nauczania historii marginalizuje jednostki należące do grup mniejszościowych" (etnicznych, narodowych, rasowych, językowych, etc.). Istnieje przekonanie, podzielane zwłaszcza przez konserwatystów, że nauczanie historii stanowi jeden $\mathrm{z}$ elementów w procesie narodowotwórczym oraz jest konieczne dla budowania postaw obywatelskich. W tym podejściu zakorzenione jest przeświadczenie, że obywatelstwo jest tożsame z przynależnością do narodu, co w ostatnich dekadach uległo zakwestionowaniu. Krytycy utożsamiania obywatelstwa z przynależnością do narodu twierdzą, że wyklucza ono te jednostki, które są obywatelami danego państwa, ale nie członkami danego narodu. Zakłada się również, że w społeczeństwach wielokulturowych, takie podejście stygmatyzuje i marginalizuje osoby należące do mniejszości narodowych, etnonarodowych, etnicznych, rasowych etc. ${ }^{58}$.

55 N. Noddings, What have we learned, dz.cyt., s. 129.

56 M. M. Suarez-Orozco, C. Sattin, Learning in the global era, [w:] Learning in the global era. International perspectives on globalization and education, red. M. M. Suarez-Orozco, University of California Press, Ross Institute, Berkeley, Los Angeles, London 2007, s. 2.

57 P. Gounari, Unlearning the official history, dz.cyt., s. 110; K. C. Barton, L. S. Levstik, History, dz.cyt., s. 356.

58 Zob. W. Kymlicka, Contemporary political philosophy, dz.cyt., s. 327 i następne; D. Heater, A history of education, dz.cyt.; J. A. Banks, Diversity and citizenship education, dz.cyt. 
Krytyka konserwatywnego podejścia do nauczania historii w społeczeństwach wielokulturowych dotyczy przedstawiania narracji z punktu dominującej ideologii cywilizacji zachodniej, a w programach szkolnych przedstawione zostają jedynie jej historyczne wydarzenia i dokonania, które są wyselekcjonowane i przekazywane uczniom w postaci gotowego zestawu dat i faktów ${ }^{59}$. Z tej perspektywy szkoły bardziej konserwują rzeczywistość historyczną niż pozwalają na krytyczną jej analizę i interpretację. Warto jednak zauważyć, że po drugiej wojnie światowej w raporcie wydanym przez UNESCO i Radę Europy zwracano uwagę na potrzebę zmiany podejścia do nauczania historii, aby zaszczepić przyszłym globalnym obywatelom „odporność na propagandę", która miałaby utrzymać pokój na świecie poprzez respektowanie praw człowieka, pluralizm oraz dziedzictwo kulturowe. W raporcie tym zwrócono uwagę na trzy obszary edukacji historycznej: zwiększenie treści o charakterze międzynarodowym, włączenie krytycznej perspektywy oraz problemów grup mniejszościowych, a także ochronę dorobku dziedzictwa kulturowego poprzez krzewienie lokalnej historii ${ }^{60}$.

Nel Noddings dostrzega kolejny problem, wynikający ze społecznej presji, jaką odczuwają nauczyciele, aby omijać pewne wątki w celu ochrony tzw. ducha narodowego, a wszelka krytyka znanych patriotycznych sloganów postrzegana jest jako antypatriotyczna ${ }^{61}$. Dlatego też w amerykańskiej debacie, ale też i coraz częściej na gruncie polskiej polityki oświatowej można dostrzec stanowiska, które nawołują do budowania nowego patriotyzmu (mówi się o „nowoczesnym patriotyzmie”, „patriotyzmie jutra”, czy „krytycznym patriotyzmie”). Ten nowy rodzaj patriotyzmu polega na wyzbyciu się wcześniejszych uprzedzeń wobec kategorii „innego”, a także ma bardziej egalitarny wymiar, który dostrzega wkład wszystkich grup w rozwój danego społeczeństwa ${ }^{62}$.

59 P. Gounari, Unlearning the official history, dz.cyt., s. 101.

60 T. Nygren, UNESCO and Council of Europe Guidelines, and History Education in Sweden, c. 1960-2002, "Education Inquiry" 2011, Vol. 2, No. 1, s. 40.

61 N. Noddings, Educating citizens for global, dz.cyt., p. 17.

62 E. Callan, Democratic patriotism, dz.cyt., s. 62. 
Wychowanie globalnych obywateli zakłada kształtowanie w nich postaw, które pozwolą im na życie w społeczeństwach wielokulturowych. Natomiast programy szkolne w większości społeczeństw wielokulturowych ciągle promują, co zostało ukazane wcześniej, etnocentryczny (europocentryczny), zachodni punkt widzenia. Dotyczy to również, a może zwłaszcza historii. Trudno zatem oczekiwać, że młodzi ludzie będą w stanie funkcjonować w globalnym świecie, znając jedynie historię własnego narodu, który podejmował jedynie słuszne i prawdziwe decyzje, np. odnośnie do prowadzonych wojen. Pamiętajmy jednak, że rozwój powszechnej edukacji był jednym z elementów procesu narodotwórczego. Ma to szczególne znaczenie w przypadku społeczeństw wielokulturowych, takich jak Stany Zjednoczone, początkowo bowiem szkoły służyły głównie białym potomkom kolonizatorów i kulturze anglosaskiej, a zatem programy kształcenia były dostosowane do ich potrzeb. Rozwijanie patriotyzmu również powiązane było z dominującą kulturą kolonizatorów, a narodowa historia służyła jego wzmocnieniu ${ }^{63}$. Funkcjonowanie systemu szkolnego $\mathrm{w}$ ramach konserwatywnego (w kulturze anglosaskiej republikańskiego kanonu), w opinii przywołanych wcześniej badaczy przedmiotu, pomija wkład i dorobek tych grup kulturowych, które historycznie były stygmatyzowane i marginalizowane, czego następstwem jest reprodukcja pożądanych postaw obywatelskich zgodnych z przyjętym konserwatywno-republikańskim kanonem.

W tym kontekście, jak zauważa P. Gounari, wyzwaniem dla systemu edukacyjnego jest wprowadzenie do programów kształcenia różnych narracji historycznych, które pokazują życie, walkę, aspirację i marzenia obydwu grup - dominującej, ale też i zdominowanej ${ }^{64}$. Wówczas nauczanie historii stanie się bardziej pluralistyczne oraz nie będzie zdominowane przez jedną, słuszną ideologię. Gounari, odwołując się do amerykańskich doświadczeń, pokazuje, że według konserwatywnego podejścia „nasza historia” wyklucza historię niewolników, Indian, Meksykanów, imigrantów oraz pomija rolę kobiet ${ }^{65}$ (feministyczne stu-

\footnotetext{
63 Tamże.

64 P. Gounari, Unlearning the official histor, dz.cyt., s. 101.

65 Tamże.
} 
dia również wskazują, że w oficjalnym programie nauczania pominięta jest perspektywa kobiet w historii) ${ }^{66}$. Nawet jeśli historie grup mniejszościowych są ukazane, to jedynie jako „poprawność polityczna, która ukazuje obraz harmonijnego współistnienia" ${ }^{67}$. Podobnie wygląda sytuacja w Wielkiej Brytanii, gdzie również w programach szkolnych pomija się rolę kobiet oraz ruchów na rzecz wyzwolenia skolonizowanych grup ${ }^{68}$. W konserwatywnym podejściu historia zaczyna się i kończy w państwie narodowym, a wszelkie inne historie mogą być jedynie tłem dla historii narodu.

Przeciwnicy odejścia od tradycyjnego nauczania historii, w którym punktem wyjścia jest państwo narodowe, uważają, że nowe podejście prowadzi nie tylko do amnezji historycznej, lecz również do wynarodowienia. W debacie amerykańskiej pojawiają się również głosy, że ważne jest skupienie się na szerokim temacie, jakim jest historia Ameryki, a nie na wąskim wycinku, w którym omawia się problem rasizmu i nierówności społecznych ${ }^{69}$. Zwolennicy tego podejścia, w opinii Gounari, wolą pozostać w sferze ustalonych pedagogii, dzięki którym nie będą musieli wyjaśniać skomplikowanych, a często i niewygodnych „faktów” historycznych ${ }^{70}$. Aczkolwiek, jak zauważył Richard Rorty „na mój gust «europocentryzm» nie jest czymś, o co powinniśmy się kłopotać. Nie ma nic aż tak złego w Europie (ani jej wypustkach, takich jak USA czy Kanada), czego nie dałoby się leczyć tolerancją i wyobraźnią [...] postmodernizm nie może uczynić więcej, w edukacji i poza nią, jak uczynić nas świadomymi tego, jak bardzo jesteśmy uzależnieni od tolerancji oraz wyobraźni - jak wciąż mało chodzi nam o nas samych"71. Postulat Rorty'ego, wygłoszony na początku lat dziewięćdziesiątych ubiegłego wieku, stanowi umiarkowane podejście wobec radykalnej polityki tamtego okresu. Pokazuje ono jednak, że ideologiczna walka między orientacją lewicową (radykalną lewicą) a konserwatywną

${ }^{66}$ Zob. P. McIntosh, Gender perspective on education, dz.cyt.

${ }^{67}$ P. Gounari, Unlearning the official history, dz.cyt., s. 101.

68 A. Osler, Patriotism, multiculturalism, dz.cyt., s. 88.

${ }^{69}$ P. Gounari, Unlearning the official history, dz.cyt., s. 104.

70 Tamże.

${ }^{71}$ R. Rorty, Edukacja i wyzwanie postnowoczesności, w: Alternatywy myślenia o/dla edukacji, red. Z. Kwieciński, IBE, Warszawa 2000, s. 148. 
(neokonserwatywną) toczy się nadal, nie tylko w przestrzeni akademickiej, lecz także odnosi się do sfery praktyki edukacyjnej.

Po trzecie, argumentuje się, że współczesne „metody nauczania historii, nie rozwijają w uczniach krytycznego myślenia”, potrzebnego w procesie wychowywania globalnych obywateli. Współczesne metody nauczania historii mają charakter frontalny, pasywny, polegający głównie na zapamiętywaniu dat i faktów (Gounari takie podejście nazywa „bankiem informacji”, ja użyłabym określenia „trening pamięci"). Wśród metod, które są promowane w literaturze przedmiotu w kontekście „nowego” podejścia do nauczania historii można wyróżnić: krytyczną analizę różnych tekstów źródłowych w celu konfrontacji postaw, dyskusję, wymianę doświadczeń, a także metodę dramy, w której uczniowie wcielają się w historyczne role i próbują rozwiązać istniejący w przeszłości problem ${ }^{72}$. Barton i Levstik wskazują, że zarówno chronologiczna narracja, jak i eksponowanie biografii wybitnych postaci nie rozwijają w uczniach zdolności krytycznego myślenia $^{73}$. Podobne stanowisko zajmują S. N. Smith, D. Fairman, twierdząc, że podręczniki szkolne do historii eksponują jedynie fakty i daty, a nie uwzględniają analizy skomplikowanych procesów społecznych ${ }^{74}$.

W tym kontekście należy zwrócić uwagę, że lekcje historii bardziej konserwują przeszłość, stają się swoistą mimesis, nie dającą możliwości odkrywania i interpretowania wydarzeń historycznych. Paradoksalnie młodzi ludzie uczestniczą w globalnym świecie, który konfrontuje ich z różnorodnością wymagającą zdolności krytycznego myślenia. Jednak jeśli nie posiadają tej zdolności, nie są w stanie analizować ani bieżących, ani historycznych wydarzeń. W procesie wychowania globalnych obywateli oczekuje się od nich otwartości, a programy szkol-

72 S. N. Smith, D. Fairman, The integration of conflict resolution into the high school curriculum: the e ample of workable peace, w: Educating citizens for global awareness, red. N. Noddings, Teachers College Press, New York 2005, s. 45; K. C. Barton, L. S. Levstik, History, dz.cyt. N. Carlsson-Paige, L. Lantieri, A changing vision of education, w: Educating citizens for global awareness, red. N. Noddings, Teachers College Press, New York 2005, s. 114.

${ }^{73}$ K. C. Barton, L. S. Levstik, History, dz.cyt., s. 358-360.

74 S. N. Smith, D. Fairman, The integration of conflict resolution, dz.cyt., s. 42. 
ne są zorientowane na pasywne przyjmowanie wiedzy, postaw, ale też i poglądów.

Thorton twierdzi, że ważne jest, aby nauczyciele potrafili angażować uczniów w dyskusję na temat globalnych problemów oraz globalnej partycypacji obywatelskiej. Odwołując się do koncepcji globalnego obywatelstwa, pokazuje on, w jaki sposób można rozwijać kompetencje wpisane $\mathrm{w}$ ten ideał $\mathrm{w}$ ramach lekcji historii. Przykładowo kwestie imigracji do Stanów Zjednoczonych w kontekście historycznym mogą być porównywane do współczesnych problemów uchodźstwa ${ }^{75}$. Noddings wskazuje, że proces wychowywania globalnych obywateli opiera się na włączaniu do lekcji historii bieżących problemów, ale również twierdzi, że to właśnie przykłady historyczne mogą zostać wykorzystane do wyjaśniania współczesnych zagadnień, np. represji politycznych $^{76}$. Z tej perspektywy wydaje się, że można „ożywić” lekcje historii, wprowadzając tematy, które dotyczą wydarzeń dziejących się współcześnie i są bardziej zrozumiałe dla młodych ludzi. W ten oto sposób, do pewnego stopnia, poprzez nauczanie historii młodzi ludzie uczą się o bieżących wydarzeniach, co z kolei wpływa na zrozumienie przeszłości. Natomiast przeszłość może tłumaczyć teraźniejszość. Innymi słowy, do czego nawołują zwolennicy edukacji globalnej, konieczne jest eksponowanie przykładów współczesnych państw, które ciągle walczą o uzyskanie niepodległości, np. Tybet, problem Kosowa, a także współczesnych reżimów, np. Białoruś, Korea Północna.

Punktem wyjścia dla wychowywania globalnych obywateli nie jest historia, lecz teraźniejszość. To ona stanowi początek wyprawy historycznej. Badania T. Nygrena pokazują, że źródłem inspiracji dla odkrywania historii mogą być filmy fabularne i dokumentalne, ale również (co często jest pomijane w szkolnym programie nauczania) historia środowiska lokalnego ${ }^{77}$.

Istnieje jednak ryzyko, że nauczyciele będą obawiali się podejmować kontrowersyjne tematy, szczególnie, jeśli mają one charakter polityczny. Im bardziej bowiem cofamy się w przeszłość, tym tematy są

\footnotetext{
75 S. J. Thornton, Incorporating internationalism, dz.cyt., s. 92.

76 N. Noddings, What have we learned, dz.cyt., s. 129.

77 T. Nygren, UNESCO and Council of Europe Guidelines, dz.cyt., s. 51.
} 
bezpieczniejsze, gdyż wkraczamy w obszar odpolityczniony. Warto również zauważyć za Osler, że historia nie jest statyczna ani raz na zawsze dana, obserwujemy nieustanną walkę o prawdę. Historia zmienia się wraz z rozwojem badań, a to z kolei wpływa na interpretację przeszłości ${ }^{78}$. Musimy jednak pamiętać, że każda próba re- interpretacji, -konstrukcji, -definicji, nie jest nigdy wolna od ideologii, na gruncie której powstała.

Na zakończenie warto odnieść się do zmiany programowej w kontekście nauczania historii w Polsce. Do pewnego stopnia zawarte $\mathrm{w}$ niej rozwiązania są odpowiedzią na przywołaną wyżej krytykę nauczania historii, pojawiającą się głównie w zachodniej literaturze przedmiotu, jak i publicznej debacie. Historia w nowym ujęciu ma służyć nie tylko przekazywaniu wiedzy, lecz również powinna rozwijać kompetencje obywatelskie. Dlatego też twórcy nowej podstawy programowej proponują również zmianę stosowanych dotychczas metod nauczania, w celu wywołania u uczniów tzw. myślenia historycznego. Widać również próby łączenia $\mathrm{w}$ materiałach kształcenia przeszłości z teraźniejszością, a także wprowadzania kompetencji z zakresu krytycznego myślenia, nazywane $\mathrm{w}$ dokumencie jako: tworzenie narracji historycznej. Wśród celów wychowawczych w ramach przedmiotu Historia i Społeczeństwo twórcy nowej podstawy programowej wyróżnili nabywanie przez uczniów samoidentyfikacji nie tylko z własnym narodem, lecz również ze społecznością europejską ${ }^{79}$. A zatem można zauważyć, że do programów szkolnych włączane są elementy związane z tożsamością, która nie jest identyfikowana jedynie z własnym narodem. Aczkolwiek w celach nauczania historii nie zostało wyeksponowane explicite odniesienie do koncepcji globalnego obywatelstwa.

78 A. Osler, Patriotism, multiculturalism, dz.cyt., s. 97.

79 Por. J. Braciszewicz, Historia w podstawie programowej ksztatcenia ogólnego. Wskazówki dla dyrektorów szkót, Ośrodek Rozwoju Edukacji, adres internetowy: www.ore.edu.pl, www.men.gov.pl, dostęp 1.09.2012. 


\section{Podsumowanie}

Podsumowując, warto zauważyć za Zbyszko Melosikiem, że pojęcie obywatelstwa stanowi „zmienną konstrukcję społeczną"80. Na przestrzeni dziejów jego źródłem była „religia, natura, społeczeństwo,

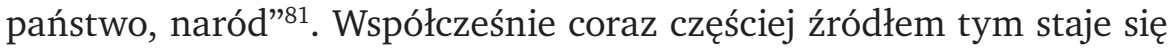
kultura kosmopolityczna oraz procesy globalizacyjne. Z punktu widzenia modernistycznego zadaniem systemu szkolnego było socjalizowanie jednostek do określonego z góry przyjętego wzoru obywatelstwa ${ }^{82}$. Wraz z pojawieniem się ponowoczesności następuje zakwestionowanie podmiotu, „przestaje być traktowany jako stabilna, jednoznaczna i «dana z góry» całość”83. Można zatem rzec, że współcześnie globalne obywatelstwo stanowi jedynie jeden z wielu dyskursów możliwych do zaakceptowania. Z kolei wiedza historyczna również podlega reinterpretacji, w zależności od tego, który z dyskursów znajduje akceptację i społeczne uznanie.

Zwolennicy koncepcji globalnego obywatelstwa (oraz globalnej edukacji) utrzymują, że nauczanie historii jedynie z perspektywy własnego narodu hamuje rozwój wspomnianej koncepcji. Z drugiej strony, jak zauważa Zbyszko Melosik, „trudno oczekiwać, aby młode pokolenie - pozbawione poczucia identyfikacji narodowej i państwowej - orientowało się na szersze (kontynentalne lub globalne) obywatelstwo"84. Być może rację mają ci badacze przedmiotu, którzy postulują, aby w procesie wychowania obywatelskiego zachować równowagę między orientacją narodową a globalną ${ }^{85}$. Nie można bowiem oczekiwać od młodego pokolenia wrażliwości na zjawiska globalne bez znajomości problemów lokalnych. Z tej perspektywy niemożliwa jest całkowita rezygnacja z wartości nacjonalistycznych w wychowaniu

\footnotetext{
80 Z. Melosik, Wychowanie obywatelskie, dz.cyt., s. 35.

81 Tamże, s. 36.

82 Tamże, s. 37.

83 Tamże, s. 42.

84 Tamże, s. 53.

85 Por. J. A. Banks, Diversity and citizenship, dz.cyt.
} 
obywatelskim. Z drugiej strony, skupianie się jedynie na tym, co narodowe może prowadzić do postaw ksenofobicznych, fundamentalnych oraz spowodować wykluczanie jednostek z uczestnictwa w globalnym świecie.

\section{Summary}

IDEA OF GLOBAL EDUCATION AND HISTORY EDUCATION

- THE PREMISES AND THE REALITY

Some academics claim that history education is a vital component in citizenship education, while the others say that its role is overestimated. In the postmodern perspective there is "the end of the past" which is, to some extend, a product of consumption society and globalization. Global education and global concerns are the part of school curricula nowadays. In this context the questions about the purposes of history education, citizenship and its relation to global education are posed: how to teach history in order to develop national identity and sensitivity towards global problems at the same time? Is it necessary to find a balance between national-state orientation and global orientation in teaching history? How to talk about history in multicultural societies, without marginalizing particular groups and without imperious imposition of the only version of "the Truth"? In order to answer to these question the reconstruction of the western debate has been made. 
